\title{
Book review: the MultiCapital scorecard: rethinking organisational performance (2016)
}

\author{
Kuntal Goswami
}

\author{
Correspondence: kuntal@acsdri.com \\ Australian Centre for Sustainable \\ Development Research \& \\ Innovation (ACSDRI) \& South Asian \\ Institute of Sustainable \\ Development (SAISD), Unit $36 / 21$ \\ South Tce, Adelaide, South Australia \\ 5000, Australia
}

\author{
Abstract \\ The book is a self-help guide on how to assess organisation's internal social, \\ economic and environmental performance based on their internal goals, and \\ stakeholders' expectations. \\ Keywords: Holistic sustainability, Multi-capital scorecard, Organisational performance
}

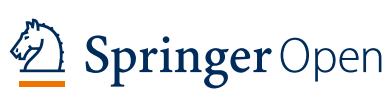

Sustainability is the goal and sustainable development is the process, however, the million-dollar question is how we might measure the level of holistic sustainability performance (economic, environment and social) of our business. In order to answer this question Martin P. Thomas and Mark W. McElroy theorised Multi-Capital Scorecard to measure level of sustainability performance in an organisational context. The authors proposed organisation to conduct a self-assessment of its impact and to adopt target driven steps to improve its accountability. These steps initiate the process of stakeholder engagement and roles out the plan to adopt requisite sustainability steps.

The book has highlighted various reasons why we need the Multi-Capital Scorecard. Some of the reasons for which we need this scorecard are for: reputation management, stakeholder engagement, and organizational learning. However, the most compelling reason the authors have put forwarded is 'Evolving Norm'. In this context authors mentioned that “... scorecard ... asks organisations to set sustainability performance standards. Related norms are made explicit and subjected to periodic review. Regardless of the sustainability agenda, aligning performance norms to the needs of stakeholders is no simple matter, and the Multi-Capital Scorecard offers a practical solution for how to perform this essential management risk ..." .

Hence, the book is a self-help guide on how to assess organisation's internal social, economic and environmental performance based on their internal goals, stakeholders' expectations. However, to reduce the subjectivity of scorecard system the book devotes a whole chapter on materiality. Hence the book is an excellent piece of work and addressed how to account for those normally unaccountable aspects of holistic sustainability. It explains how to:

(c) The Author(s). 2020 Open Access This article is licensed under a Creative Commons Attribution 4.0 International License, which permits use, sharing, adaptation, distribution and reproduction in any medium or format, as long as you give appropriate credit to the original author(s) and the source, provide a link to the Creative Commons licence, and indicate if changes were made. The images or other third party material in this article are included in the article's Creative Commons licence, unless indicated otherwise in a credit line to the material. If material is not included in the article's Creative Commons licence and your intended use is not permitted by statutory regulation or exceeds the permitted use, you will need to obtain permission directly from the copyright holder. To view a copy of this licence, visit http://creativecommons.org/licenses/by/4.0/. 
1) scope and ascertain Materiality aspect of sustainability accounting;

2) determine Areas of Impacts (AOIs) of an organisation; and

3) implement the Scorecard.

The book has 10 chapters and some of the highlights of each chapters as follows:

Chapter-1: The chapter explained the need for Multi-Capital scorecard. The authors argue that by adopting their prescribed scorecard model organisations can: address environmental and social challenges, improve adaptive capacity and stakeholder engagement techniques. In addition, the model can also assist organisations to bring about qualitative improvement in management information system, organisational learning process and safeguard reputation management.

Chapter-2: The second chapter introduces readers with the concept of capital and its six vital categorisations such as natural capital, human capital, social and relationship capital, constructed capital, internal economic capital, external economic capital. In the end the concept of "context-based sustainability" is introduced.

Chapter-3: The chapter provided theoretical as well as operational methodology of the Multi-Capital Scorecard. The authors presented detail steps to practitioners on how to apply performance scoring mechanism as well as how to report performance. Chapter-4: This chapter dealt with practice of the Multi-Capital Scorecard in respect to financial performance.

Chapter-5 \& 6: Both these chapters provided practical demonstration of the MultiCapital Scorecard in the context of single and group companies.

Chapter-7 \& 8: These chapters educated readers with two important challenging topics relating to measurement: materiality and how to measure intangibles. Chapter 7 explained absolute \& relative materiality concepts and provided materiality template for social, economic and environmental performance measurement. Chapter- 8 discussed how to apply the Multi-Capital Scorecard in the context of intangibles such as brand.

Chapter - 9: The chapter discussed few contemporary key topics such as Integrated Reporting; Multi-Capital Scorecard in relation to the Integrated Reporting, DoubleLoop Learning, and External Assurance.

Chapter-10: The concluding chapter provided a broad overview on how Multi-Capital Scorecard works and tried to close intellectual gaps between academics and practitioners, and bridged interest of shareholders and other stakeholders.

Finally, in the appendix the book has provided foundational theory explaining how to use of context-based metrics and other thought-provoking intellectual concepts.

Acknowledgements

I thanks Mr Martin P. Thomas one of the authors of the book for giving me the opportunity to review this book.

Authors' contributions

The Book Review is written by Dr Kuntal Goswami on request of the author Mr Martin P. Thomas. The author(s) read and approved the final manuscript. 
Availability of data and materials

Not Applicable.

Competing interests

No Competing Interest.

Received: 13 September 2019 Accepted: 14 April 2020

Published online: 07 May 2020

\section{Publisher's Note}

Springer Nature remains neutral with regard to jurisdictional claims in published maps and institutional affiliations.

Submit your manuscript to a SpringerOpen ${ }^{\odot}$ journal and benefit from:

- Convenient online submission

- Rigorous peer review

- Open access: articles freely available online

- High visibility within the field

- Retaining the copyright to your article

Submit your next manuscript at $\boldsymbol{\nabla}$ springeropen.com 